\title{
Global research output on HIV/AIDS-related medication adherence from 1980 to 2017
}

Waleed M. Sweileh

\begin{abstract}
Background: "Human Immunodeficiency Virus (HIV)" and Acquired Immunodeficiency Syndrome (AIDS) are global health burden. Medication adherence in people living with HIV (PLWH) is a key element in reducing morbidity and mortality. Quantitative and qualitative assessment of research activity helps identify research gaps as well as efforts implemented to improve adherence behaviors in PLWH. The aim of the current study was to assess and analyze literature on HIV/AIDS-related medication adherence using bibliometric methods.

Methods: SciVerse Scopus was used to accomplish the purpose of the current study. The study period included all times up to 2017. The analysis was restricted to documents published in academic journals.

Results: Search strategy retrieved 3021 documents with an average of 32.5 citations per document, an $h$-index of 136, and an average of 4.4 authors per documents. The volume of literature on HIV/AIDS-related medication adherence constituted $1.3 \%$ of the overall HIV/AIDS literature. There was a significant $(p<0.01 ; r=0.9)$ correlation between the growth of publications in AIDS-related stigma and medication adherence. The regions of America (567.9) had the highest research output per one million infected people (567.9) followed by the European region (314.3), Western Pacific Region (70.7), Eastern Mediterranean region (31.4), South East Asia (34.0), and Africa (19.3). Geographical distribution of publications showed an active contribution of certain countries in the Southern and Eastern region of Sub-Saharan Africa. Harvard University $(8.4 \% ; n=254)$ was the most active institution. The top cited documents focused on the impact of adherence on disease outcome and the impact of text messages on improving medication adherence.
\end{abstract}

Conclusion: Research on medication adherence in PLWH showed regional variations. International research collaboration with high burden regions such as Sub-Saharan Africa needs to be strengthened to achieve the global target of ending AIDS as a public health threat by 2030.

Keywords: Medication adherence, HIV, AIDS, Bibliometric analysis, VOSviewer, ArcGIS 10.1

\section{Background}

Human Immunodeficiency Virus (HIV) and its clinical manifestation of "Acquired Immunodeficiency Syndrome (AIDS)" are considered major global public health challenge $[1,2]$. It is estimated that 36.7 million people worldwide are living with HIV and approximately one million died of HIV-related causes globally [3]. Currently, no cure is available for HIV infection. However, effective antiretroviral therapy (ART) is considered the optimum available therapy for people living with HIV (PLWH) and those at substantial risk [4]. The early use of combination ART, known as highly active antiretroviral treatment (HAART), has

Correspondence: waleedsweileh@yahoo.com

Department of Physiology, Pharmacology/Toxicology, Division of Biomedical

Sciences, College of Medicine and Health Sciences, An-Najah National

University, Nablus, Palestine

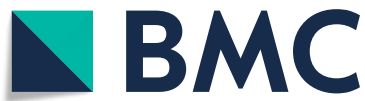

resulted in increased survival in PLWH [5]. In 2016, World Health Organization (WHO) released the guideline for treating and preventing HIV infection which included recommendations to provide lifelong ART to all categories of PLWH regardless of their CD4 cell count [6]. According to WHO fact sheet updated in November 2016, expanding ART therapy to all PLWH and expanding prevention choices can help minimize millions of deaths and new infections expected by the year 2030 [7].

Prevention and control of HIV infection largely depend on adherence to recommended treatment $[8,9]$. Poor adherence, especially at levels less than $95 \%$, adversely affects the HIV outcome [10-13]. Adherence can be problematic in low and middle-income countries because of inadequate healthcare services, limited health literacy, and lack

C The Author(s). 2018 Open Access This article is distributed under the terms of the Creative Commons Attribution 4.0 International License (http://creativecommons.org/licenses/by/4.0/), which permits unrestricted use, distribution, and reproduction in any medium, provided you give appropriate credit to the original author(s) and the source, provide a link to the Creative Commons license, and indicate if changes were made. The Creative Commons Public Domain Dedication waiver (http://creativecommons.org/publicdomain/zero/1.0/) applies to the data made available in this article, unless otherwise stated. 
of social support [14-17]. Even in developed countries, less than half of surveyed patients had $100 \%$ adherence to HIV medications [18]. Studies on adherence to recommended HIV therapy as well as barriers to $100 \%$ adherence are, therefore, vital in all world regions and countries. Actually, the importance of high-level adherence to HIV therapy had resulted in a vast number of publications that investigated factors associated with non-adherence and beneficial strategies that can be used to overcome such factors [19-21]. Interventional studies to improve medication adherence in PLWH included implementation of recent mobile technology which proved to be cost-effective compared with other interventional studies [22].

The need to assess research trends in medication adherence in PLWH is important for researchers, health policymakers, and clinical practitioners. Such importance is due to the crucial role of adherence in improving survival of infected people and minimizing the spread of infection given that medication adherence varies with different societies and different world regions [23, 24]. Assessing growth and research trends are also important for improving the volume and quality of research, identifying research gaps that future studies need to focus on, and identifying geographical spots with low research productivity relative to their HIV/AIDS national burden. To date, no studies had been published to summarize global research efforts, research trends, and geographical distribution of research output in medication adherence in general and in PLWH in particular. It should be emphasized here that several reports have been published about HIV/ AIDS research productivity in general [25-28], but none was published about research output on medication adherence in specific. Therefore, the aim of this study was to give a comprehensive analysis, both quantitative and qualitative, of scientific literature on medication adherence in PLWH.

\section{Methods}

In this study, a bibliometric methodology was implemented. Bibliometric analysis is not the same as systematic reviews or scoping reviews. In bibliometric analysis, one single database is used to provide baseline information and to identify research gaps for future studies and funding purposes [29, 30]. SciVerse Scopus or Web of Knowledge is usually selected to carryout bibliometric analysis. No grey literature is included in bibliometric analysis. Therefore, bibliometric analysis is not comprehensive of all literature. In contrast, systematic reviews have a specific research question that needs to be answered using a limited number of publications. In systematic reviews, literature published in different databases, including grey literature, is retrieved and filtered based on a preset inclusion and exclusion criteria. This is the reason why in systematic reviews, but not in bibliometric analysis, the retrieved documents will include a large percentage of duplicate documents. In systematic reviews, researchers might follow up with the analysis and carry out meta-analysis, which is not the case in bibliometric analysis [31, 32]. For scoping reviews, the nature and extent of research evidence are analyzed [33, 34].

\section{Search strategy and keywords}

SciVerse Scopus, an online database containing abstracts and citations of more than 23,000 journals in various fields [35], was used to achieve the purpose of this study. Furthermore, SciVerse Scopus was used since it was previously used in several bibliometric studies including those pertaining to HIV/AIDS [36-44]. The implemented search strategy was shown in the additional file (Additional file 1). Quotation marks and asterisks were used in the search strategy to enhance the accuracy and comprehensiveness of the results. The search strategy consisted of combined search queries of keywords related to HIV/AIDS and keywords related to medication adherence. Keywords used were partially obtained from previously published literature on AIDS-related medication adherence [21, 23, 45, 46]. An exclusion step was implemented to eliminate potential false positive documents. This study was limited to documents published in academic journals any time up to 2016 .

\section{Bibliometric indicators and mapping}

The quality of retrieved publications was assessed using Hirsh-index ( $h$-index) [47]. Author keywords were also analyzed and visualized using VOSviewer software [48]. ArcGIS 10.1 software was used to map the geographic distribution of the retrieved literature [49]. The analysis also included distribution of research output based on world health organization (WHO) world regions [50]. For the calculation of the number of publications per one million PLWH, the WHO data on numbers of infected people in each region was used [51]. Prevalence data for each of the top ten counties were obtained from CIA World Factbook [52]. All data presented in this study were obtained by analysis of data retrieved on July 29, 2018.

\section{Results}

\section{Types of retrieved documents}

The search strategy retrieved 3021 journal documents. The same search strategy retrieved approximately 232,000 documents on HIV/AIDS. Therefore, the literature on medication adherence in PLWH constituted $1.3 \%$ of total literature on HIV/AIDS published during the same study period. Retrieved documents were mostly research articles $(2520 ; 83.4 \%)$ and review articles (255; $8.4 \%)$. The types of documents encountered in the 
retrieved literature were shown in Table 1 . Thirteen different languages were encountered in the abstracts of retrieved articles, mostly English $(2857 ; 94.6 \%)$ and Spanish (99; 3.3\%). In total, 642 (21.3\%) documents were published in journals within the scope of psychology while 401 (13.3\%) documents were published in journals within the scope of social sciences and humanities. The remaining documents (1972; 65.5\%) were published in various journals within biomedical and health fields.

\section{Most frequent keywords}

Analysis of the most frequent keywords, excluding those pertaining to HIV/AIDS and adherence, were shown in Fig. 1. The most frequently encountered author keywords in retrieved the literature were depression/depressive symptoms, stigma, /substance use, Sub- Saharan Africa, children, viral load, poverty/food insecurity, quality of life, and several others.

\section{Growth of publications}

Publications on HIV/AIDS-related medication adherence started as early as 1992 . The number of publications increased with time and reached a maximum of approximately 200 documents per year in the last five years of the study period. Table 2 shows the annual number of publications on medication adherence and the annual number of publications on HIV/AIDS in general. The percentage of publications on medication adherence from the corresponding number of HIV/AIDS publications showed a linear increase with time. The growth of publications on medication adherence started one decade later than that on HIV/AIDS. The growth of publications on medication adherence was parallel to that of HIV/AIDS until early 2000 (Fig. 2). In the last decade of the study period, the growth of publications on medication adherence showed stronger upward increase than that of HIV/AIDS.

Table 1 Types of retrieved documents

\begin{tabular}{lll}
\hline Types of document & $\begin{array}{l}\text { Number of publications } \\
N=2031\end{array}$ & $\%$ \\
\hline Article & 2520 & 83.4 \\
Review & 255 & 8.4 \\
Letter & 100 & 3.3 \\
Conference Paper & 61 & 2.0 \\
Note & 42 & 1.4 \\
Editorial & 27 & 0.9 \\
Short Survey & 15 & 0.5 \\
Article in Press (undefined) & 1 & 0.0 \\
\hline
\end{tabular}

\section{Growth of citations}

Retrieved publications received 98,175 citations, an average of 32.5 citations per document, and an $h$-index of 136. Table 3 shows the mean number of citations per publication per year and the cumulative number of citations. The mean number of citations was highest for documents published in early 2000 shown as a peak in Fig. 3. The cumulative number of citations, on the other hand, showed a linear upward pattern.

\section{Geographical distribution of publications}

Analysis of the retrieved documents indicated that authors in the region of Americas made the largest contribution (1931; 63.9\%), followed by those in the European region (723; $23.9 \%)$, the region of Africa $(497 ; 16.5 \%)$, the region of South East Asia (119; 3.9\%), the Western Pacific region (106; 3.5\%), and the Eastern Mediterranean region (11; $0.4 \%)$. Figure 4 shows the contribution of each WHO region to the retrieved documents as well as the number of publications per one million PLWH in each WHO region. Figure 4 showed that the region of Americas (567.9) had the highest research productivity stratified by number of PLWH (per one million) followed by the European region (314.3), Western Pacific Region (70.7), Eastern Mediterranean region (31.4), South East Asia (34.0), and Africa (19.3). Researchers from 102 countries contributed to retrieved literature. Figure 5 is a geographical mapping of retrieved documents.

\section{Most active countries}

The list of these top ten active countries was shown in Table 4. The USA ranked first in research output $(57.4 \% ; n=1733)$. Two countries in the top ten active list were from African region; one from Latin America, one from South East Asia, and the remaining were from Northern America and Western Europe. No significant correlation was found between the number of publications and the prevalence rate of HIV/AIDS. When the research output was standardized by calculating the percentage of publications on medication adherence relative to overall HIV/AIDS research activity in HIV/AIDS field, Uganda ranked first followed by Brazil and South Africa in.

\section{Most active institutions}

Table 5 shows the top ten active institutions/organizations in the field of medication adherence among PLWH. All top ten active institutions/organizations were based in the USA. Harvard University $(8.4 \% ; n=254)$ was the most active institution followed by University of California, San Francisco $(7.4 \% ; n=223)$, and Johns Hopkins University $(7.1 \% ; n=214)$. The top ten active 


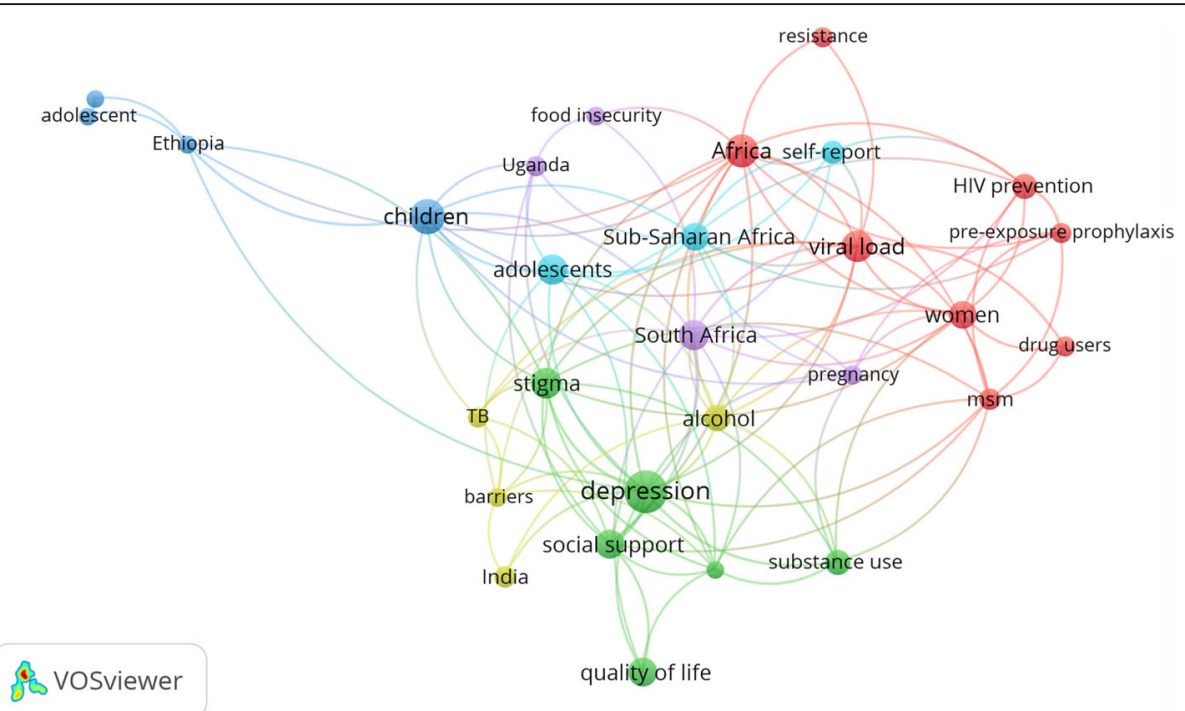

Fig. 1 Network visualization map of author keywords with a minimum frequency of 10 times

institutions/organizations included seven academic institutions and three research/clinical organizations.

\section{International collaboration}

International collaboration in the field of HIV/AIDS-related medication adherence research was visualized for countries with a minimum productivity of 40 publications (Fig. 6). The map shows that the USA occupies the center with many connecting line indicative of a large number of collaborating countries with the USA in this field. The relative strength of collaboration, measured by the thickness of the connecting lines between countries, was

Table 2 Growth of publications on HIV/AIDS in general and publications on medication adherence in specific

\begin{tabular}{|c|c|c|c|c|c|c|c|}
\hline Year & $\begin{array}{l}\text { Number of } \\
\text { publications on } \\
\text { medication } \\
\text { adherence }\end{array}$ & $\begin{array}{l}\text { Number of overall } \\
\text { publications on } \\
\text { HIV/AIDS }\end{array}$ & $\begin{array}{l}\% \text { of publication on } \\
\text { medication adherence from } \\
\text { overall publications }\end{array}$ & Year & $\begin{array}{l}\text { Number of } \\
\text { publications on } \\
\text { medication } \\
\text { adherence }\end{array}$ & $\begin{array}{l}\text { Number of overall } \\
\text { publications on } \\
\text { HIV/AIDS }\end{array}$ & $\begin{array}{l}\% \text { of publication } \\
\text { on medication } \\
\text { adherence from } \\
\text { overall publications }\end{array}$ \\
\hline 1980 & 0 & 21 & 0 & 1999 & 49 & 7213 & 0.68 \\
\hline 1981 & 0 & 20 & 0 & 2000 & 60 & 6941 & 0.86 \\
\hline 1982 & 0 & 27 & 0 & 2001 & 80 & 6726 & 1.19 \\
\hline 1983 & 0 & 131 & 0 & 2002 & 123 & 6732 & 1.83 \\
\hline 1984 & 0 & 168 & 0 & 2003 & 121 & 7037 & 1.72 \\
\hline 1985 & 0 & 275 & 0 & 2004 & 112 & 7611 & 1.47 \\
\hline 1986 & 0 & 468 & 0 & 2005 & 114 & 8027 & 1.42 \\
\hline 1987 & 0 & 1615 & 0 & 2006 & 166 & 8376 & 1.98 \\
\hline 1988 & 0 & 3163 & 0 & 2007 & 143 & 9066 & 1.58 \\
\hline 1989 & 0 & 3727 & 0 & 2008 & 155 & 9051 & 1.71 \\
\hline 1990 & 0 & 4835 & 0 & 2009 & 152 & 9203 & 1.65 \\
\hline 1991 & 0 & 5256 & 0 & 2010 & 174 & 9350 & 1.86 \\
\hline 1992 & 2 & 5794 & 0.03 & 2011 & 202 & 9792 & 2.06 \\
\hline 1993 & 2 & 6156 & 0.03 & 2012 & 202 & 10,118 & 2 \\
\hline 1994 & 2 & 6237 & 0.03 & 2013 & 226 & 10,377 & 2.18 \\
\hline 1995 & 4 & 6820 & 0.06 & 2014 & 244 & 10,230 & 2.39 \\
\hline 1996 & 6 & 7684 & 0.08 & 2015 & 212 & 9628 & 2.2 \\
\hline 1997 & 19 & 7465 & 0.25 & 2016 & 201 & 9498 & 2.12 \\
\hline 1998 & 35 & 7539 & 0.46 & 2017 & 215 & 9316 & 2.31 \\
\hline
\end{tabular}




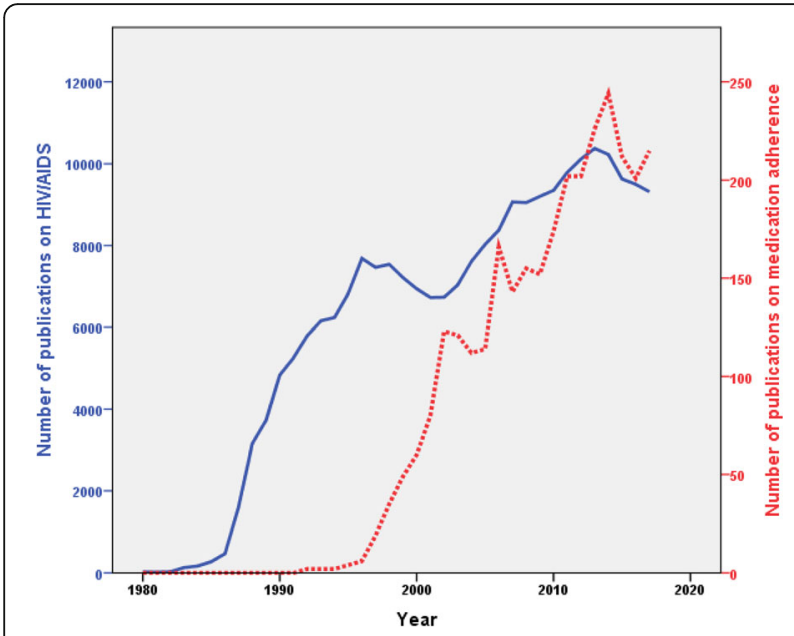

Fig. 2 Growth of publications on HIV/AIDS - related medication adherence relative to the overall growth of publications on HIV/AIDS in general

highest for USA - South Africa, USA - Uganda, a USA Canada, USA - UK, and the USA - Kenya.

\section{Most preferred journals}

In total, 634 different journals participated in publishing the retrieved documents; 39 of them were in the field of HIV/AIDS. The top ten active journals included eight journals in the field of HIV/AIDS, one in the field of infectious diseases, and one journal with multidisciplinary scope (Table 6). The top productive journal in this field was AIDS Care $(8.0 \% ; n=241)$ followed by AIDS and Behavior journal $(7.3 \% ; n=220)$. Six journals in the top

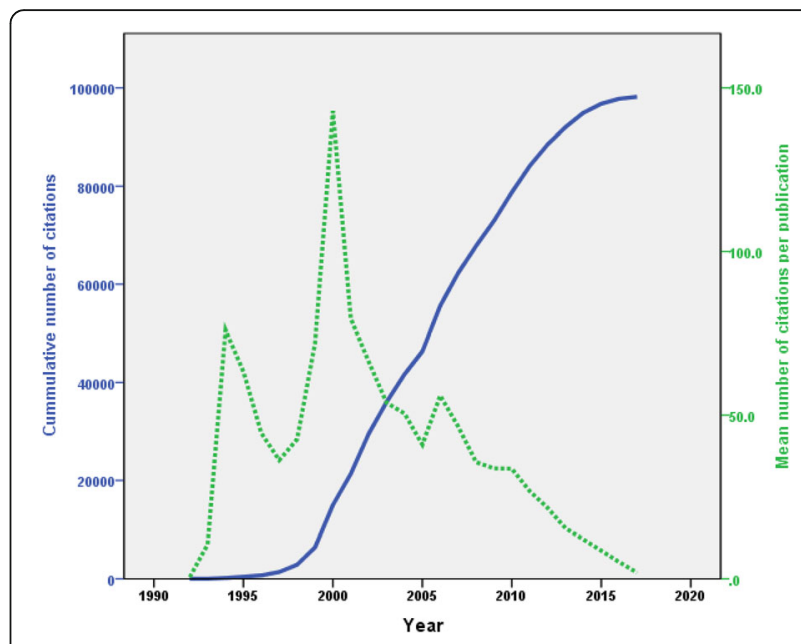

Fig. 3 Annual and cumulative number of citations

active list were published from the USA, three from the UK, and one from the Netherlands.

\section{Authorship analysis}

The average number of authors per document was 4.4. Table 7 is a list of top ten active authors in the field along with their affiliation as it appeared in Scopus. Professor Bangsberg, D.R. was the most prolific author $(3.1 \% ; n=92)$ followed by Professor Safren, S.A. $(1.7 \% ; n=49)$.

\section{Highly cited articles}

Highly cited articles on HIV/AIDS-related medication adherence were identified. The top cited articles for the period from 1992 to 2007 were shown in Additional file 2. The top cited article for the

Table 3 Mean number of citations per document per year and cumulative number of citations

\begin{tabular}{|c|c|c|c|c|c|c|c|c|c|}
\hline Year & $\begin{array}{l}\text { Number of } \\
\text { publications } \\
\text { on medication } \\
\text { adherence }\end{array}$ & $\begin{array}{l}\text { Number of } \\
\text { citations }\end{array}$ & $\begin{array}{l}\text { Mean number } \\
\text { of citations per } \\
\text { document }\end{array}$ & $\begin{array}{l}\text { Cumulative } \\
\text { number of } \\
\text { citations }\end{array}$ & Year & $\begin{array}{l}\text { Number of } \\
\text { publications } \\
\text { on medication } \\
\text { adherence }\end{array}$ & $\begin{array}{l}\text { Number of } \\
\text { citations }\end{array}$ & $\begin{array}{l}\text { Mean number } \\
\text { of citations per } \\
\text { document }\end{array}$ & $\begin{array}{l}\text { Cumulative } \\
\text { number of } \\
\text { citations }\end{array}$ \\
\hline 1992 & 2 & 1 & 0.5 & 1 & 2005 & 114 & 4679 & 41.0 & 46,330 \\
\hline 1993 & 2 & 21 & 10.5 & 22 & 2006 & 166 & 9293 & 56.0 & 55,623 \\
\hline 1994 & 2 & 152 & 76.0 & 174 & 2007 & 143 & 6649 & 46.5 & 62,272 \\
\hline 1995 & 4 & 253 & 63.3 & 427 & 2008 & 155 & 5525 & 35.6 & 67,797 \\
\hline 1996 & 6 & 267 & 44.5 & 694 & 2009 & 152 & 5115 & 33.7 & 72,912 \\
\hline 1997 & 19 & 688 & 36.2 & 1382 & 2010 & 174 & 5841 & 33.6 & 78,753 \\
\hline 1998 & 35 & 1490 & 42.6 & 2872 & 2011 & 202 & 5391 & 26.7 & 84,144 \\
\hline 1999 & 49 & 3523 & 71.9 & 6395 & 2012 & 202 & 4369 & 21.6 & 88,513 \\
\hline 2000 & 60 & 8571 & 142.9 & 14,966 & 2013 & 226 & 3477 & 15.4 & 91,990 \\
\hline 2001 & 80 & 6358 & 79.5 & 21,324 & 2014 & 244 & 2939 & 12.0 & 94,929 \\
\hline 2002 & 123 & 8163 & 66.4 & 29,487 & 2015 & 212 & 1830 & 8.6 & 96,759 \\
\hline 2003 & 121 & 6508 & 53.8 & 35,995 & 2016 & 201 & 1016 & 5.1 & 97,775 \\
\hline 2004 & 112 & 5656 & 50.5 & 41,651 & 2017 & 215 & 400 & 1.9 & 98,175 \\
\hline
\end{tabular}




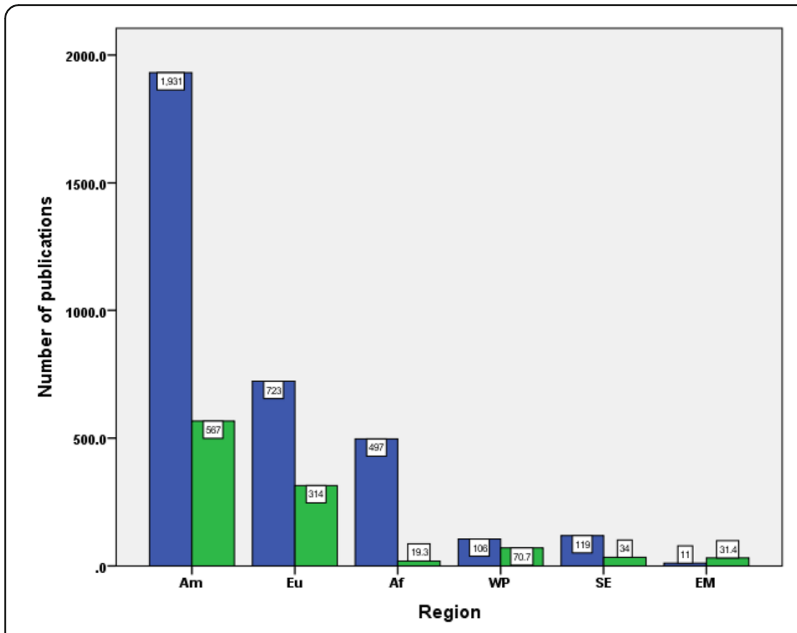

Fig. 4 contribution of different WHO regions to retrieved literature adjusted by the number of HIV infected people. Am: Americas; Eu: Europe; Af: Africa; WP: Western Pacific; SE: South Eastern; EM: Eastern Mediterranean

specified period received a total of 2410 citations, an average of 134 citations per year since the time of publication [53]. This study concluded that adherence to protease inhibitor therapy of $95 \%$ or greater gave an optimum virologic outcome in PLWH. The top cited articles for the period from 2008 to 2017 were also shown in Additional file 2. The top cited article received 599 citations, an average of 75 citations per year since the time of publication [54].

\section{Role of HIV-related stigma}

Stigma research activity in HIV/AIDS showed parallel growth to that of medication adherence with a correlation coefficient of 0.912 and a $p$-value of $<0.01$.
Figure 7 shows the growth of publications in both HIV/AIDS-related stigma and HIV/AIDS-related medication adherence. Research activity on HIV/ AIDS-related stigma started earlier than that on medication adherence. However, the number of publications on medication adherence was higher than that on AIDS-related stigma research. The total number of publications on HIV/AIDS-related stigma was 2510; approximately $83.1 \%$ of that on HIV/AIDS - related medication adherence research output.

\section{Role of mobile technology in medication adherence}

In total, 149 (4.9\%) documents about the role of mobile and phone technology in adherence to AIDS therapy were retrieved. These documents were published during the period from 2003 to 2017. The documents received 3643 citations, an average of 24.4 citations per document. The highest citation was achieved by an article published in The Lancet and the article discussed the role of short mobile messages in improving adherence to AIDS therapy in Kenya [54]. This study indicated a significant increase of adherence rate and a significant reduction in viral load in patients receiving phone messages as reminders of medication adherence. The second highly cited article in the role of mobile technology in adherence to AIDS therapy was also published on a group of patients in Sub-Saharan Africa and concluded that SMS reminders increased adherence in resourcelimited settings [55].

\section{Discussion}

\section{Growth of publications}

This study aimed to analyze literature on HIV/ AIDS-related medication adherence and present the

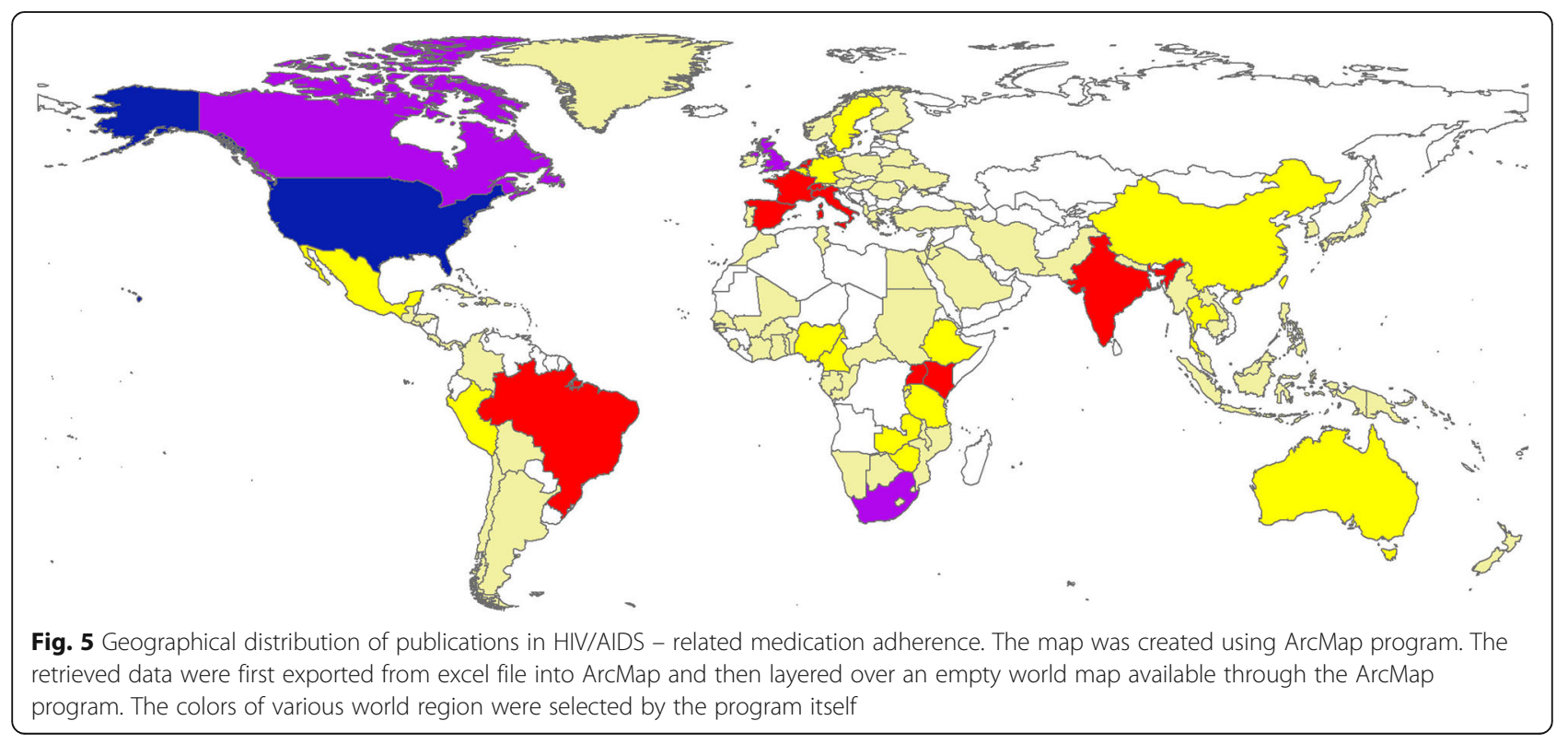


Table 4 Top ten active countries in HIV/AIDS - related medication adherence

\begin{tabular}{lllllll}
\hline SCR & Country & $\begin{array}{l}\text { Number of } \\
\text { publications } \\
N=3021\end{array}$ & $\%$ & $\begin{array}{l}\text { Number of publications } \\
\text { in HIV/AIDS field; } \\
N=232,000\end{array}$ & $\begin{array}{l}\text { \% of medication adherence } \\
\text { publications from overall } \\
\text { HIV/AIDS research }\end{array}$ & $\begin{array}{l}\text { prevalence (\%) of } \\
\text { HIV among adults } \\
(15-49 \text { years) }\end{array}$ \\
\hline 1st & United States & 1733 & 57.4 & 91,600 & 1.9 & 0.6 \\
2nd & South Africa & 236 & 7.8 & 10,138 & 2.3 & 18.92 \\
3rd & United Kingdom & 199 & 6.6 & 18,915 & 1.1 & 0.33 \\
4th & Canada & 177 & 5.9 & 8362 & 2.1 & 0.3 \\
5th & Spain & 130 & 4.3 & 8334 & 1.6 & 0.42 \\
6th & France & 118 & 3.9 & 13,131 & 0.9 & 0.4 \\
7th & Brazil & 115 & 3.8 & 4974 & 2.3 & 0.55 \\
8th & Uganda & 102 & 3.4 & 2742 & 3.7 & 6.8 \\
9th & Italy & 80 & 2.6 & 9678 & 0.8 & 0.28 \\
9th & Switzerland & 80 & 2.6 & 5037 & 1.6 & 0.26
\end{tabular}

SCR, Standard competition ranking;

${ }^{a}$ Equal countries have the same ranking number, and then a gap is left in the ranking numbers

results in bibliometric maps and tables. The results of this study showed a noticeable growth in this field relative to the overall HIV/AIDS research output indicative of the importance of this topic in the global fight against HIV/AIDS particularly in countries with limited resources or those with high social stigma against HIV infected people. The growth of publications in HIV/IDS-related medication adherence could be attributed to several factors. First, the natural increase in global research and publications on HIV/AIDS in general, secondary to international calls to decrease the global health burden of HIV/ AIDS [56]. However, it should be emphasized that the results presented in this study indicated that the growth of publication on medication adherence showed relatively faster upward growth than that on HIV/AIDS in general. Second, the shift in HIV/AIDS disease paradigm from an acute untreatable infectious disease to a chronic illness that requires a high degree of adherence [57-59]. Third, the international aids and support to African countries with high prevalence of HIV/ AIDS which created a momentum of international collaboration between developed countries and many African countries in research pertaining to HIV/AIDS including medication adherence research [60, 61]. The finding that Uganda and South Africa ranked among the top ten active countries at the global level indicated the role of international collaboration in fighting HIV/AIDS in Africa. Fourth, the introduction and advancement of mobile technology which provided a new frontier for medication adherence research in the field of HIV/AIDS $[62,63]$. The current study showed that medication adherence research pertaining to HIV/AIDS started in the early 1990s while reports on HIV/AIDS started in the early 1980s, exhibiting a one-decade gap. This gap is most probably due to the advancement in HIV/AIDS

Table 5 Top ten active institutions/organizations in HIV/AIDS - related medication adherence

\begin{tabular}{|c|c|c|c|}
\hline$S C R^{a}$ & Institution/organization & $\begin{array}{l}\text { Number of publications } \\
\mathrm{N}=2031\end{array}$ & $\%$ \\
\hline $1 s t$ & Harvard University & 254 & 8.4 \\
\hline 2nd & University of California, San Francisco & 223 & 7.4 \\
\hline $3 \mathrm{rd}$ & Johns Hopkins University & 214 & 7.1 \\
\hline 4th & Massachusetts General Hospital & 148 & 4.9 \\
\hline 5 th & VA Medical Centers & 124 & 4.1 \\
\hline 6th & University of California, Los Angeles & 111 & 3.7 \\
\hline 7th & University of Washington, Seattle & 102 & 3.4 \\
\hline 8th & The University of North Carolina at Chapel Hill & 95 & 3.1 \\
\hline 9th & Centers for Disease Control and Prevention & 91 & 3.0 \\
\hline 10th & Columbia University in the City of New York & 87 & 2.9 \\
\hline
\end{tabular}

SCR, Standard competition ranking:

${ }^{a}$ Equal institutions have the same ranking number, and then a gap is left in the ranking numbers 


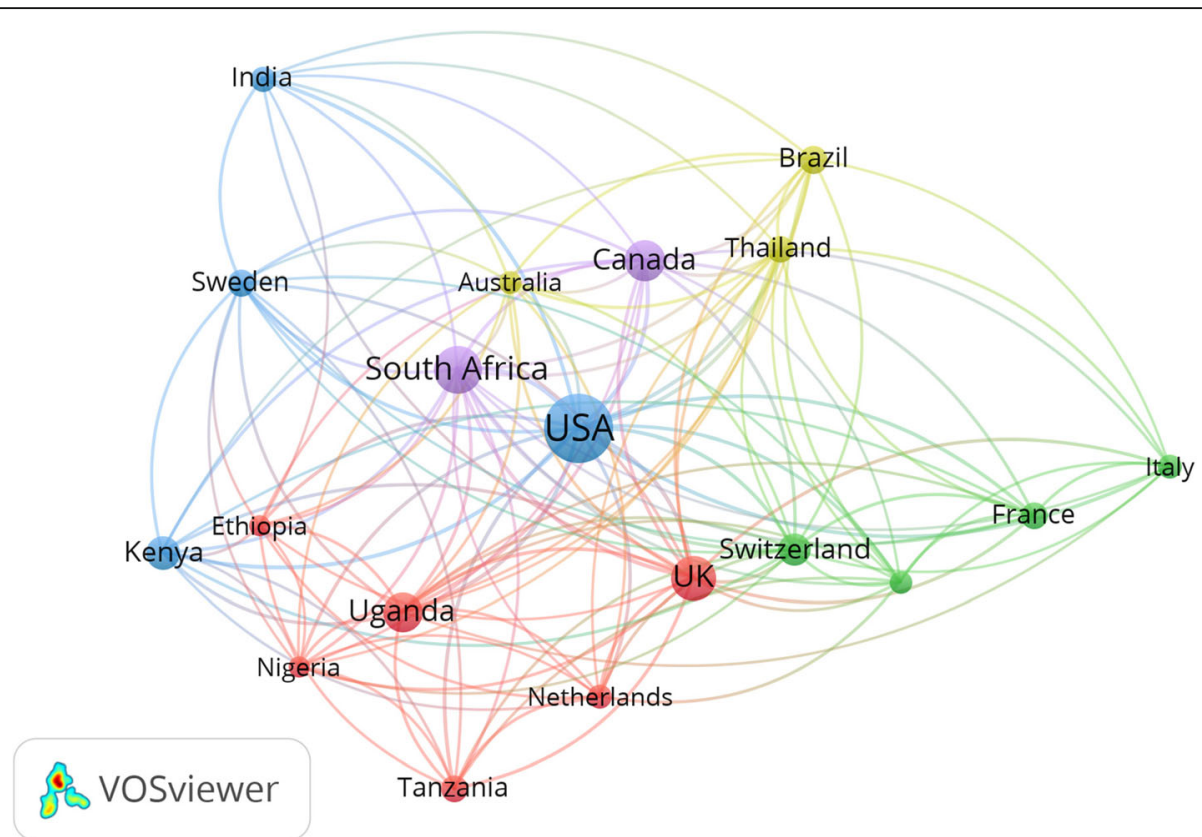

Fig. 6 Network visualization map of international collaboration in countries with minimum productivity of 30 publications

therapeutic approaches, which resulted in HIV/AIDS being envisioned as a chronic illness that needs continuous adherence to medications.

\section{Geographical distribution of publications}

HIV/AIDS is a global public health problem, with the problem in Africa considered to pose the greatest challenge, given a variety of barriers including poor access to medications, unsafe sex behaviors, stigma, and poverty. As a result, many African countries have significant numbers of PLWH $[64,65]$. The contribution of African countries to medication adherence research was evident but inadequate given the health barriers and social challenges that PLWH might face in Africa. The contribution of certain countries such as South Africa and Uganda was quantitatively among the top active countries. However, when this research productivity was stratified with numbers of PLWH, the productivity was low. Relatively low research productivity from Africa and other world regions could be attributed to the limited number of clinicians and researchers in the field of infectious diseases in general and in the field of AIDS in particular. Furthermore, the lack of financial resources and academic funding needed to support publication fees in high-quality journals could be

Table 6 Top ten active journals in HIV/AIDS - related medication adherence

\begin{tabular}{|c|c|c|c|c|c|c|}
\hline$\overline{\mathrm{SCR}}$ & Journal Name & $\begin{array}{l}\text { Number of publications } \\
\text { on medication adherence (\%) } \\
\mathrm{N}=3021\end{array}$ & $\%$ & $\begin{array}{l}\text { Number of publications } \\
\text { on HIV/AIDS in general (\%) } \\
\mathrm{N}=232,000\end{array}$ & $\%$ & Country \\
\hline $1 s t$ & AIDS Care & 241 & 8.0 & 2691 & 9.0 & UK \\
\hline 2nd & AIDS And Behavior & 220 & 7.3 & 2239 & 9.8 & Netherlands \\
\hline $3 r d$ & Journal Of Acquired Immune Deficiency Syndromes & 212 & 7.0 & 5403 & 3.9 & USA \\
\hline 4 th & AIDS Patient Care And STDs & 173 & 5.7 & 1805 & 9.6 & USA \\
\hline 5 th & AIDS & 104 & 3.4 & 8648 & 1.2 & USA \\
\hline 6th & Plos One & 95 & 3.1 & 3897 & 2.4 & USA \\
\hline 7th & Journal Of The Association Of Nurses In AIDS Care & 66 & 2.2 & 879 & 7.5 & USA \\
\hline 8th & International Journal Of STD And AIDS & 44 & 1.5 & 2162 & 2.0 & USA \\
\hline 9th & Clinical Infectious Diseases & 43 & 1.4 & 2955 & 1.5 & UK \\
\hline 10th & HIV Clinical Trials & 31 & 1.0 & 572 & 5.4 & UK \\
\hline
\end{tabular}

SCR, Standard competition ranking;

${ }^{a}$ Equal journalss have the same ranking number, and then a gap is left in the ranking numbers 
Table 7 Top ten active researchers (authors) in HIV/AIDS - related medication adherence

\begin{tabular}{|c|c|c|c|c|}
\hline$\overline{S C R^{a}}$ & Author name & Frequency & $\%(N=3201)$ & Affiliation as shown in Scopus \\
\hline $1 \mathrm{st}$ & Bangsberg, D.R. & 92 & 3.1 & Massachusetts General Hospital, Division of Infectious Diseases, Boston, United States \\
\hline 2nd & Safren, S.A. & 49 & 1.7 & University of Miami, Coral Gables, United States \\
\hline $3 \mathrm{rd}$ & Montaner, J.S.G. & 43 & 1.4 & British Columbia Centre for Excellence in HIV-AIDS, Vancouver, Canada \\
\hline $3 \mathrm{rd}$ & Chesney, M.A. & 43 & 1.4 & UCSF School of Medicine, Osher Center for Integrative Medicine, San Francisco, United States \\
\hline $3 \mathrm{rd}$ & Gross, R. & 43 & 1.4 & $\begin{array}{l}\text { University of Pennsylvania, Center for Clinical Epidemiology and Biostatistics, Philadelphia, } \\
\text { United States }\end{array}$ \\
\hline 6th & Spire, B. & 41 & 1.3 & $\begin{array}{l}\text { Sciences Economiques and Sociales de la Santé and Traitement de l'Information Médicale, } \\
\text { Marseille, France }\end{array}$ \\
\hline 6th & Kalichman, S.C. & 41 & 1.3 & University of Connecticut, Department of Psychology, Storrs, United States \\
\hline 8th & Wilson, I.B. & 35 & 1.2 & Brown University, Department of Health and Human Services, Providence, United States \\
\hline 9th & Simoni, J.M. & 33 & 1.1 & University of Washington, Seattle, Department of Psychology, Seattle, United States \\
\hline 9th & Haberer, J.E. & 33 & 1.1 & Massachusetts General Hospital, Boston, United States \\
\hline 9th & Nachega, J.B. & 33 & 1.1 & $\begin{array}{l}\text { Universiteit Stellenbosch, Department of Medicine and Centre for Infectious Diseases, } \\
\text { Stellenbosch, South Africa }\end{array}$ \\
\hline 9th & Amico, K.R. & 33 & 1.1 & University of Michigan School of Public Health, Ann Arbor, United States \\
\hline
\end{tabular}

SCR, Standard competition ranking;

${ }^{a}$ Equal authors have the same ranking number, and then a gap is left in the ranking numbers

another potential reason for the limited contribution of African countries to global research output in this field. Researchers in Africa and other world regions are keen to publish and contribute to the advancement of health situation but the financial obstacles and academic responsibilities act as major barriers. Furthermore, regulations regarding academic tenure and promotion in scientific institutions in Africa and other world regions do not pressure researchers and clinicians to be engaged in research activity. One potential mechanism to encourage and increase research output from Africa and other world regions is through research networking and research collaboration with researchers in developed countries. Such

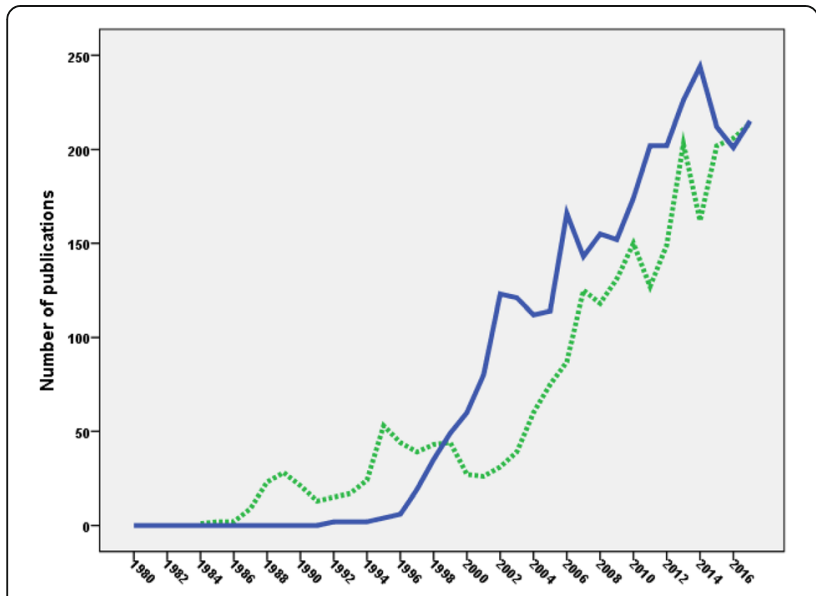

Fig. 7 Comparative growth of publications on HIV/AIDS - related medication adherence (blue line) and HIV/AIDS - related stigma (green line) collaboration can help researchers in Africa in manuscript writing and submission in addition to the potential of financial funding for publishing in high-quality journals. Actually, the findings of the current study indicated that the contribution of African countries to medication adherence research was made through international collaboration with developed countries such as USA, UK, and Canada.

\section{Most frequent author keywords}

Results indicated that keywords such as stigma, depression, and drug abuse were most frequently encountered author keywords in HIV/AIDS-related medication adherence literature. Stigma has been reported, particularly in low and middle - income countries, to be a real and important barrier to medication adherence [66-71]. The findings that research activity in HIV/AIDS-related stigma was parallel to that of AIDS-related medication adherence is indicative of inter-relationship between stigma and adherence in PLWH [3, 15, 72-75]. The keyword "depression" showed up as a frequent author keyword possibly due to the role of depression in medication non-adherence. Patients with HIV/AIDS have impaired psychological health that could negatively affect their adherence to medications [76]. Substance abuse also showed up as a frequent author keyword possibly due to its role in medication non-adherence and mortality among users [77].

\section{Citation analysis}

The finding that the $h$-index was 136 indicates that a large number of citations and a large number of readers showed interest in this field. For example, the $h$-index for publication on antimicrobial resistance of uropathogens [78], 
multidrug resistance tuberculosis [38], and anti-malarial drug resistance [79] was lower than that reported in the current study. Furthermore, the $h$-index obtained in this study was also higher than that reported for health topics unrelated to infectious diseases $[37,79,80]$. One potential explanation for the high $h$-index relative to other non-infectious diseases is the fact that non-adherence in HIV/AIDS patients might have more deleterious and acute effects than that for other chronic diseases such as diabetes. For example, medication non-adherence in diabetes could be replaced with diet restriction and exercise, which is not the case in HIV/AIDS. Furthermore, non-adherence in patients with HIV/AIDS might lead to a serious resistance problem to anti-viral drugs, which is not the case with anti-diabetic medications [81-86]. Medication adherence to anti-HIV medications is of extreme importance given that more than $95 \%$ adherence to HIV medications is required to minimize and suppress the viral load and control the disease, however this is not the case in chronic diseases such as diabetes mellitus where medium adherence might still be adequate in controlling the chronic disease [87-90].

\section{Most active journals, institutions, and authors}

The most active journals in adherence to AIDS therapy were those in the specific field of AIDS. There are more than 70 journals in the specific field of AIDS/HIV indexed in Scopus. These journals created a scientific forum for researchers and clinicians to discuss hot topics in the field of AIDS. The involvement of these journals in publishing research in AIDS-related medication adherence is an indication of the high importance of this topic to the scientific community. However, most of these journals were published in Northern America and Europe, which might explain the large contribution of researchers from developed countries to publications appearing in these journals. Most institutions in the active list were also from high-income countries in Americas and Europe. It seems that academic institutions in the USA receive good funding for research pertaining to AIDS/HIV in general and to aspects pertaining to issues with serious impact on public health in particular. The presence of large numbers of PLWH in the USA is another potential reason for the high involvement of US researchers and institutions in AIDS-related medication adherence.

\section{Limitations and future direction}

Medication adherence in PLWH is a global health issue and publication in this field is growing. It was the goal of this study to retrieve all relevant literature. However, not all journals, particularly those issued in Africa, are indexed in Scopus. Therefore, it is possible that some publications were missed. Furthermore, the title search gives accurate data but might cause some loss of publications in which the keywords were mentioned in abstract and not in the title. In this study, quality of publications was measure by citation analysis and $h$-index, which is not an ideal method to measure quality because self-citations might influence the values of citations and give a false impression of high impact. Despite these limitations, this study is the first to discuss literature on adherence to AIDS therapy in a bibliometric methodology. The findings of the current study should direct the efforts of researchers, human right activists, clinicians, and health policymakers to encourage research that point out barriers to medication adherence in world regions with a high burden of infected people. Furthermore, international health agencies need to direct and allocate funds and financial support to research in which technology could be used to overcome barriers to adherence. Social and human right activists need to speak out on the role of stigma and discrimination in medication adherence and such should implement social policies to minimize stigma and, therefore, enhance adherence. Clinicians in their practice settings should use mobile technology as a method of following up and communication with PLWH. This is extremely important in world regions where stigma and decimation as a real barrier to medication adherence. Clinicians should pressure the pharmaceutical industry and international health organization to provide AIDS therapy with minimum cost to low resourced regions. The Pharmaceutical industry could also help in improving adherence by manufacturing combination products with a minimum frequency of dosing and minimum possible cost. Nurses could also play a key role in improving adherence. Nurses in AIDS clinics should provide people with HIV full information regarding the importance of medication adherence in AIDS and the potential hazards of non-adherence to prescribed therapy. The fight against AIDS is a global and collective effort and people from the entire clinical spectrum, including clinical researchers, need to play a positive role in this regard.

\section{Conclusion}

The results of this study showed (1) an increase in the number of publications with time and that this increase was parallel to that of AIDS-related stigma literature; (2) the region of Africa had the least research productivity in HIV/AIDS-related medication adherence when productivity was adjusted by the number of PLWH; (3) depression and stigma were one of the most frequent author keywords in HIV/AIDS-related medication adherence literature; finally (4) the $h$-index of retrieved literature was relatively high indicative of the importance of the topic to researchers and clinicians. Research on medication adherence in PLWH is a key component for the plan to 
minimize the global health burden of HIV/AIDS particularly in the presence of effective anti-HIV therapies that were proven to increase survival of PLWH. International research collaboration needs to be strengthened, particularly with countries where HIV/AIDS burden is high and national resources are scarce.

\section{Additional files}

Additional file 1: Research strategy with keywords used and implemented to retrieve literature in HIV/AIDS - related medication adherence (DOC $32 \mathrm{~kb}$ )

Additional file 2: Top 10 cited documents on HIV/AIDS-medication adherence (DOCX $38 \mathrm{~kb}$ )

\section{Abbreviations}

HIV AIDS: Human Immunodeficiency Virus Acquired Immunodeficiency Syndrome; PLWH: People living with HIV; WHO: World Health Organization

\section{Acknowledgments}

The author would like to thank An-Najah National University for facilitating this study.

\section{Availability of data and materials}

Data pertaining to this study could be retrieved using Scopus and search strategy available in additional file.

\section{Authors' contributions}

WS initiated the idea, designed the study, analyzed the data, wrote the manuscript, and did the submission. The authors read and approved the final manuscript

\section{Ethics approval and consent to participate}

Not applicable.

\section{Consent for publication}

Not applicable.

\section{Competing interests}

The author declares that he has no competing interests.

\section{Publisher's Note}

Springer Nature remains neutral with regard to jurisdictional claims in published maps and institutional affiliations.

Received: 5 April 2018 Accepted: 26 September 2018

Published online: 10 October 2018

References

1. Arora V, Kadian M, Sharma K, Yadav M. A challenge towards defeating AIDS: a review. World J Pharm Pharm Sci. 2015:4(3):1321-38.

2. Wang H, Wolock TM, Carter A, Nguyen G, Kyu HH, Gakidou E, Hay SI, Mills EJ, Trickey A, Msemburi W. Estimates of global, regional, and national incidence, prevalence, and mortality of HIV, 1980-2015: the global burden of disease study 2015. The lancet HIV. 2016;3(8):e361-87.

3. UNAIDS; Global AIDS Update 2016. [http://www.unaids.org/en/resources/ documents/2016/Global-AIDS-update-2016.];

4. Cohen MS, Chen YQ, McCauley M, Gamble T, Hosseinipour MC, Kumarasamy N, Hakim JG, Kumwenda J, Grinsztejn B, Pilotto JH, et al. Prevention of HIV-1 infection with early antiretroviral therapy. N Engl J Med. 2011:365(6):493-505.

5. Moore RD, Chaisson RE. Natural history of HIV infection in the era of combination antiretroviral therapy. AIDS. 1999;13(14):1933-42.

6. World Health Organization; Consolidated guidelines on the use of antiretroviral drugs for treating and preventing HIV infection Recommendations for a public health approach [http://www.who.int/hiv/ pub/arv/arv-2016/en/]

7. World Health Organization; HIV/AIDS fact sheet [http://www.who.int/ mediacentre/factsheets/fs360/en/];
8. McNabb J, Ross JW, Abriola K, Turley C, Nightingale CH, Nicolau DP. Adherence to highly active antiretroviral therapy predicts virologic outcome at an innercity human immunodeficiency virus clinic. Clin Infect Dis. 2001;33(5):700-5.

9. Wood E, Hogg RS, Yip B, Harrigan PR, O'Shaughnessy MV, Montaner JS. The impact of adherence on CD4 cell count responses among HIV-infected patients. J Acquir Immune Defic Syndr. 2004;35(3):261-8.

10. Robbins GK, Johnson KL, Chang Y, Jackson KE, Sax PE, Meigs JB, Freedberg KA. Predicting virologic failure in an HIV clinic. Clin Infect Dis. 2010;50(5):779-86.

11. Marconi VC, Grandits G, Okulicz JF, Wortmann G, Ganesan A, Crum-Cianflone N, Polis M, Landrum M, Dolan MJ, Ahuja SK, et al. Cumulative viral load and virologic decay patterns after antiretroviral therapy in HIV-infected subjects influence CD4 recovery and AIDS. PLoS One. 2011:6(5):e17956.

12. Sethi AK, Celentano DD, Gange SJ, Moore RD, Gallant JE. Association between adherence to antiretroviral therapy and human immunodeficiency virus drug resistance. Clin Infect Dis. 2003;37(8):1112-8.

13. Ekstrand ML, Shet A, Chandy S, Singh G, Shamsundar R, Madhavan V, Saravanan S, Heylen E, Kumarasamy N. Suboptimal adherence associated with virological failure and resistance mutations to first-line highly active antiretroviral therapy (HAART) in Bangalore, India. Int Health. 2011;3(1):27-34

14. Enriquez M, McKinsey DS. Strategies to improve HIV treatment adherence in developed countries: clinical management at the individual level. HIV AIDS (Auckl). 2011;3:45-51.

15. Croome N, Ahluwalia M, Hughes LD, Abas M. Patient-reported barriers and facilitators to antiretroviral adherence in sub-Saharan Africa. AIDS. 2017; 31(7):995-1007.

16. Murray LK, Semrau K, McCurley E, Thea DM, Scott N, Mwiya M, Kankasa C, Bass J, Bolton P. Barriers to acceptance and adherence of antiretroviral therapy in urban Zambian women: a qualitative study. AIDS Care. 2009:21(1):78-86.

17. Shubber Z, Mills EJ, Nachega JB, Vreeman R, Freitas M, Bock P, Nsanzimana S, Penazzato M, Appolo T, Doherty M, et al. Patient-reported barriers to adherence to antiretroviral therapy: a systematic review and meta-analysis. PLoS Med. 2016;13(11):e1002183.

18. Nachega J, Morroni C, Sherer K, Schechter M, Rockstroh J, Solomon S, Zuniga J. HIV treatment adherence levels, patient literacy, and health care provider-patient communication: a global survey of 2,035 adults. In: th Annual International Conference on HIV Treatment and Prevention Adherence, Miami, FL. 2011:2011.

19. Kim SH, Gerver SM, Fidler S, Ward H. Adherence to antiretroviral therapy in adolescents living with HIV: systematic review and meta-analysis. AIDS 2014;28(13):1945-56.

20. Mey A, Plummer D, Dukie S, Rogers GD, O'Sullivan M, Domberelli A. Motivations and barriers to treatment uptake and adherence among people living with HIV in Australia: a mixed-methods systematic review. AIDS Behav. 2017:21(2):352-85.

21. Uthman OA, Oladimeji O, Nduka C. Adherence to antiretroviral therapy among HIV-infected prisoners: a systematic review and meta-analysis. AIDS Care. 2017;29(4):489-97.

22. Cook PF, Carrington JM, Schmiege SJ, Starr W, Reeder B. A counselor in your pocket: feasibility of mobile health tailored messages to support HIV medication adherence. Patient Prefer Adherence. 2015:9:1353-66.

23. Heestermans T, Browne JL, Aitken SC, Vervoort SC, Klipstein-Grobusch K. Determinants of adherence to antiretroviral therapy among HIV-positive adults in sub-Saharan Africa: a systematic review. BMJ Glob Health. 2016;1(4):e000125.

24. Ware NC, Idoko J, Kaaya S, Biraro IA, Wyatt MA, Agbaji O, Chalamilla G, Bangsberg DR. Explaining adherence success in sub-Saharan Africa: an ethnographic study. PLoS Med. 2009;6(1):e11.

25. Khan M, James R, Sundaram N, Wu S, Eang MT, Vonthanak S, Coker R. Less research on tuberculosis than HIV and malaria when research agendas are poorly coordinated: a systematic review of research outputs from Cambodia. Int J Infect Dis. 2017:56:25-9.

26. Levandowski DC, Ritt GC, Vescovi G, Barth B. Adolescence and HIV/AIDS: a bibliometric analysis of Brazilian scientific production during 1980-2013. Adolescencia e Saude. 2016;13(1):74-83.

27. Mugomeri E, Bekele BS, Mafaesa M, Maibvise C, Tarirai C, Aiyuk SE. A 30-year bibliometric analysis of research coverage on HIV and AIDS in Lesotho. Health Res Policy Syst. 2017;15(1):21.

28. Uuskula A, Toompere K, Laisaar KT, Rosenthal M, Purjer ML, Knellwolf A, Laara E, Des Jarlais DC. HIV research productivity and structural factors associated with HIV research output in European Union countries: a bibliometric analysis. BMJ Open. 2015;5(2):e006591. 
29. Wallin JA. Bibliometric methods: pitfalls and possibilities. Basic Clin Pharmacol Toxicol. 2005;97(5):261-75.

30. Van Raan AF: Advances in bibliometric analysis: research performance assessment and science mapping. Bibliometrics Use and Abuse in the Review of Research Performance 2014:17-28.

31. Peters MD, Godfrey CM, Khalil H, Mclnerney P, Parker D, Soares CB. Guidance for conducting systematic scoping reviews. Int J Evid Based Healthc. 2015;13(3):141-6.

32. Møller A, Myles P. What makes a good systematic review and meta-analysis? $\mathrm{Br} J$ Anaesth. 2016;117(4):428-30.

33. Grant MJ, Booth A. A typology of reviews: an analysis of 14 review types and associated methodologies. Health Inf Libr J. 2009;26(2):91-108.

34. Levac D, Colquhoun H, O'Brien KK. Scoping studies: advancing the methodology. Implement Sci. 2010;5(1):69.

35. Scopus.; SciVerse Scopus fact sheet. SciVerse ${ }^{\circledast}$ Scopus. [http://www.elsevier. com/online-tools/scopus. ]; Feburary 12, 2018.

36. Sweileh WM, Al-Jabi SW, AbuTaha AS, Zyoud SH, Anayah FMA, Sawalha AF. Bibliometric analysis of worldwide scientific literature in mobile - health: 2006-2016. BMC Med Inform Decis Mak. 2017;17(1):72.

37. Sweileh WM. Bibliometric analysis of medicine - related publications on refugees, asylum-seekers, and internally displaced people: 2000 - 2015. BMC Int Health Hum Rights. 2017;17(1):7.

38. Sweileh WM, AbuTaha AS, Sawalha AF, Al-Khalil S, Al-Jabi SW, Zyoud SH. Bibliometric analysis of worldwide publications on multi-, extensively, and totally drug - resistant tuberculosis (2006-2015). Multidiscip Respir Med. 2016;11:45.

39. Sweileh WM, Al-Jabi SW, Sawalha AF, AbuTaha AS, Zyoud SH. Bibliometric analysis of worldwide publications on antimalarial drug resistance (2006-2015). Malar Res Treat. 2017;2017:6429410.

40. Sweileh WM, Al-Jabi SW, Sawalha AF, AbuTaha AS, Zyoud SH. Bibliometric analysis of publications on campylobacter: (2000-2015). J Health Popul Nutr. 2016;35(1):39.

41. Sweileh WM, Al-Jabi SW, Zyoud SH, Sawalha AF. Bibliometric analysis of literature in pharmacy education: 2000-2016. Int J Pharm Pract. 2018.

42. Zyoud SH, Waring WS, Al-Jabi SW, Sweileh WM. Global cocaine intoxication research trends during 1975-2015: a bibliometric analysis of web of science publications. Subst Abuse Treat Prev Policy. 2017;12(1):6.

43. Sweileh WM. Bibliometric analysis of peer-reviewed literature in transgender health (1900 - 2017). BMC Int Health Hum Rights. 2018;18(1):16.

44. Sweileh WM. Bibliometric analysis of literature in AIDS-related stigma and discrimination. Transl Behav Med. 2018.

45. Hudelson C, Cluver L. Factors associated with adherence to antiretroviral therapy among adolescents living with HIV/AIDS in low- and middleincome countries: a systematic review. AIDS Care - Psychological and SocioMedical Aspects of AIDS/HIV. 2015;27(7):805-16.

46. Detsis M, Tsioutis C, Karageorgos SA, Sideroglou T, Hatzakis A, Mylonakis E. Factors associated with HIV testing and HIV treatment adherence: a systematic review. Curr Pharm Des. 2017;23(18):2568-78.

47. Hirsch JE. An index to quantify an individual's scientific research output Proc Natl Acad Sci U S A. 2005;102(46):16569-72.

48. Van Eck NJ, Waltman L. Software survey: VOSviewer, a computer program for bibliometric mapping. Scientometrics. 2010;84(2):523-38.

49. ESRl; ArcGIS 10.1 Available Soon [https://blogs.esri.com/esri/arcgis/2012/06/ 11/arcgis-10-1-available-soon/]; July 01, 2017.

50. World Health Organization (WHO); WHO regional offices [http://www.who. int/about/regions/en/]; August 10, 2017.

51. World Health Organization (WHO); People living with HIV by WHO region, 2016 [http://www.who.int/hiv/data/en/]; August 10, 2017.

52. CIA World factbook; COUNTRY COMPARISON: HIV/AIDS - ADULT PREVALENCE RATE [https://www.cia.gov/library/publications/the-worldfactbook/rankorder/2155rank.html]; August 10, 2017.

53. Paterson DL, Swindells S, Mohr J, Brester M, Vergis EN, Squier C, Wagener MM, Singh N, Hudson B. Adherence to protease inhibitor therapy and outcomes in patients with HIV infection. Ann Intern Med. 2000;133(1):21-30

54. Lester RT, Ritvo P, Mills EJ, Kariri A, Karanja S, Chung MH, Jack W, Habyarimana J, Sadatsafavi M, Najafzadeh M, et al. Effects of a mobile phone short message service on antiretroviral treatment adherence in Kenya (WelTel Kenya1): a randomised trial. Lancet. 2010;376(9755):1838-45.

55. Pop-Eleches $C$, Thirumurthy $H$, Habyarimana JP, Zivin JG, Goldstein MP, De Walque D, Mackeen L, Haberer J, Kimaiyo S, Sidle J, et al. Mobile phone technologies improve adherence to antiretroviral treatment in a resourcelimited setting: a randomized controlled trial of text message reminders. AIDS. 2011;25(6):825-34.

56. Ortblad KF, Lozano R, Murray CJL. The burden of HIV: insights from the global burden of disease study 2010. AIDS. 2013;27(13):2003-17.

57. Deeks SG, Lewin SR, Havlir DV. The end of AIDS: HIV infection as a chronic disease. Lancet. 2013;382(9903):1525-33.

58. Maina GM, Caine V, Mill J, Wimmer R. Exploring the meaning of living with HIV as a chronic illness in Kenya: a narrative inquiry. Commun Med. 2016; 13(2):215-26.

59. Mignone J, Migliardi P, Harvey C, Davis J, Madariaga-Vignudo L, Pindera C. HIV as chronic illness: caregiving and social networks in a vulnerable population. J Assoc Nurses AIDS Care. 2015;26(3):235-45.

60. Ferrari LL. Catholic and non-Catholic NGOs fighting HIV/AIDS in subSaharan Africa: issue framing and collaboration. International Relations. 2011;25(1):85-107.

61. Onyancha OB, Ocholla DN. Country-wise collaborations in HIV/ AIDS research in Kenya and South Africa, 1980-2005. Libri. 2007:57(4):239-54.

62. Muessig KE, LeGrand S, Horvath KJ, Bauermeister JA, Hightow-Weidman LB. Recent mobile health interventions to support medication adherence among HIV-positive MSM. Curr Opin HIV AIDS. 2017;12(5):432-41.

63. Webb B: The acceptability of Mobile phone technology as a medication adherence intervention in the HIV-positive community. Brandman University; 2016

64. Maartens G, Celum C, Lewin SR. HIV infection: epidemiology, pathogenesis, treatment, and prevention. Lancet. 2014;384(9939):258-71.

65. Idele P, Gillespie A, Porth T, Suzuki C, Mahy M, Kasedde S, Luo C. Epidemiology of HIV and AIDS among adolescents: current status, inequities, and data gaps. JAIDS Journal of Acquired Immune Deficiency Syndromes. 2014;66:S144-53.

66. Higuera PC, Ramírez MLP, Ávila AD, Mora-Talla TD. stigma, discrimination and adherence to treatment of children with HIV and AIDS. A bioethical perspective. Acta Bioethica. 2016;22(2):331-40.

67. Sweeney SM, Vanable PA. The association of HIV-related stigma to HIV medication adherence: a systematic review and synthesis of the literature. AIDS Behav. 2016;20(1):29-50.

68. Lyimo RA, Stutterheim SE, Hospers HJ, De Glee T, Van Der Ven A, De Bruin M. Stigma, disclosure, coping, and medication adherence among people living with HIV/AIDS in northern Tanzania. AIDS Patient Care STDs. 2014; 28(2):98-105

69. Mprah A. Knowledge, opinions, and experiences of stigma as a barrier to antiretroviral therapy adherence among HIV community volunteers and health care givers in an urban slum, in Uganda. Annals of Tropical Medicine and Public Health. 2016;9(5):331-9.

70. Katz IT, Ryu AE, Onuegbu AG, Psaros C, Weiser SD, Bangsberg DR, Tsai AC. Impact of HIV-related stigma on treatment adherence: systematic review and meta-synthesis. J Int AIDS Soc. 2013;16(3 Suppl 2).

71. Zafra-Tanaka JH, Ticona-Chavez E. Stigma related to HIV/AIDS associated with adherence to antiretroviral therapy in patients of a public hospital in Lima, Peru 2014. Revista Peruana de Medicina Experimental y Salud Publica. 2016;33(4):625-32.

72. Midtbø V, Shirima V, Skovdal M, Daniel M. How disclosure and antiretroviral therapy help HIV-infected adolescents in sub-Saharan Africa cope with stigma. Afr J AIDS Res. 2012;11(3):261-71.

73. Eyassu MA, Mothiba TM, Mbambo-Kekana NP. Adherence to antiretroviral therapy among HIV and AIDS patients at the Kwa-Thema clinic in Gauteng Province, South Africa. African Journal of Primary Health Care and Family Medicine. 2016;8(2):1-7.

74. Van Loggerenberg F, Gray D, Gengiah S, Kunene P, Gengiah TN, Naidoo K, Grant AD. A qualitative study of patient motivation to adhere to combination antiretroviral therapy in South Africa. AIDS Patient Care STDs. 2015;29(5):299-306

75. Chan BT, Tsai AC: HIV stigma trends in the general population during antiretroviral treatment expansion: analysis of 31 countries in sub-Saharan Africa, 2003-2013. J Acquir Immune Defic Syndr 2016, 72(5):558-564.

76. Gibbie T, Hay M, Hutchison CW, Mijch A. Depression, social support and adherence to highly active antiretroviral therapy in people living with HIV/ AIDS. Sex Health. 2007;4(4):227-32.

77. Malta M, Strathdee SA, Magnanini MM, Bastos FI. Adherence to antiretroviral therapy for human immunodeficiency virus/acquired immune deficiency syndrome among drug users: a systematic review. Addiction. 2008;103(8):1242-57. 
78. Sweileh WM, Al-Jabi SW, Zyoud SH, Sawalha AF, Abu-Taha AS. Global research output in antimicrobial resistance among uropathogens: a bibliometric analysis (2002-2016). J Glob Antimicrob Resist. 2017.

79. Sweileh WM. Bibliometric analysis of literature on toxic epidermal necrolysis and Stevens-Johnson syndrome: 1940 - 2015. Orphanet J Rare Dis. 2017;12(1):14.

80. Sweileh WM. Bibliometric analysis of literature on female genital mutilation: (1930 - 2015). Reprod Health. 2016;13(1):130.

81. Boullé C, Kouanfack C, Laborde-Balen G, Aghokeng AF, Boyer S, Carrieri MP, Kazé S, Mben JM, Dontsop M, Spire B, et al. Prediction of HIV drug resistance based on virologic, immunologic, clinical, and/or adherence criteria in the stratall ANRS 12110/ESTHER trial in Cameroon. Clin Infect Dis. 2013;57(4):604-7.

82. Ndembi N. Adherence to antiretroviral therapy, retention in care and hiv drug resistance in Nigeria. Curr HIV Res. 2015;13(4):260-1.

83. Rusconi $\mathrm{S}$. The impact of adherence to HIV/AIDS antiretroviral therapy on the development of drug resistance. Futur Virol. 2017;12(5):239-41.

84. Meresse M, March L, Kouanfack C, Bonono RC, Boyer S, Laborde-Balen G, Aghokeng A, Suzan-Monti M, Delaporte E, Spire B, et al. Patterns of adherence to antiretroviral therapy and HIV drug resistance over time in the Stratall ANRS 12110/ESTHER trial in Cameroon. HIV Medicine. 2014;15(8):478-87.

85. Kijak GH, Kim JH. Timing, adherence, resistance, and ... Persistence? New insight into the mechanisms of failure of HIV type 1 postexposure prophylaxis. J Infect Dis. 2013;208(10):1542-4.

86. von Wyl V, Klimkait T, Yerly S, Nicca D, Furrer H, Cavassini M, Calmy A, Bernasconi E, Böni J, Aubert V, et al. Adherence as a predictor of the development of class-specific resistance mutations: the Swiss HIV cohort study. PLoS One. 2013;8(10).

87. Phillips T, Brittain K, Mellins CA, Zerbe A, Remien RH, Abrams EJ, Myer L, Wilson IB. A self-reported adherence measure to screen for elevated HIV viral load in pregnant and postpartum women on antiretroviral therapy. AIDS Behav. 2017;21(2):450-61.

88. Sevelius JM, Saberi P, Johnson MO. Correlates of antiretroviral adherence and viral load among transgender women living with HIV. AIDS Care Psychological and Socio-Medical Aspects of AIDS/HIV. 2014;26(8):976-82.

89. Farmer A, Wang X, Ganesan A, Deiss RG, Agan BK, O'Bryan TA, Akers K, Okulicz JF. Factors associated with HIV viral load "blips" and the relationship between self-reported adherence and efavirenz blood levels on blip occurrence: a case-control study. AIDS Res Ther. 2016;13(1).

90. Chikwari CD, Ferrand RA, Simms V. Association between self-reported adherence and HIV viral load suppression among older children and adolescents. J Acquir Immune Defic Syndr. 2017.

Ready to submit your research? Choose BMC and benefit from:

- fast, convenient online submission

- thorough peer review by experienced researchers in your field

- rapid publication on acceptance

- support for research data, including large and complex data types

- gold Open Access which fosters wider collaboration and increased citations

- maximum visibility for your research: over $100 \mathrm{M}$ website views per year

At BMC, research is always in progress.

Learn more biomedcentral.com/submissions 